\title{
Short-Sellers: Informed but Restricted
}

Fernando D. Chague

RODRIGo DE-LOSSO

Alan de Genaro

BRUno GiovannetTi 


\title{
DEPARTMENT OF ECONOMICS, FEA-USP \\ WORKING PAPER № 2013-05
}

\section{Short-Sellers: Informed but Restricted}

\author{
Fernando D. Chague (fchague@usp.br) \\ Rodrigo De-Losso (delosso@usp.br) \\ Alan De Genaro (adario@bvmf.com.br) \\ Bruno Giovannetti (bcg@usp.br)
}

\begin{abstract}
:
According to theory, the level of short-selling can predict short-run future returns throughout two channels. One is related to the demand-side of the stock lending market: short-sellers are informed. The other is related to the supply-side: short-sellers are restricted. Measuring the importance of each channel is empirically challenging once, in general, supply and demand in the stock lending market are not directly observable. This paper takes advantage of a unique dataset that contains actual shifts in lending supply for stocks on the Brazilian market, and proposes an identification strategy for the effects of both supply and demand on stock prices. We find that both channels are important.
\end{abstract}

Keywords: Short-seller; short-selling; short-selling restrictions

JEL Codes: G12, G14 


\title{
Short-sellers: informed but restricted.
}

\author{
Fernando Chague, Rodrigo De-Losso ${ }^{\dagger}$ \\ Alan De Genaro $\ddagger$ and Bruno Giovannetti ${ }^{\S}$
}

March 27, 2013

\begin{abstract}
According to theory, the level of short-selling can predict short-run future returns throughout two channels. One is related to the demand-side of the stock lending market: short-sellers are informed. The other is related to the supply-side: short-sellers are restricted. Measuring the importance of each channel is empirically challenging once, in general, supply and demand in the stock lending market are not directly observable. This paper takes advantage of a unique dataset that contains actual shifts in lending supply for stocks on the Brazilian market, and proposes an identification strategy for the effects of both supply and demand on stock prices. We find that both channels are important.
\end{abstract}

\footnotetext{
* Department of Economics, University of Sao Paulo. E-mail: fernando.chague@gmail.com

${ }^{\dagger}$ Department of Economics, University of Sao Paulo. E-mail: delosso@usp.br

${ }^{\ddagger}$ BMF\&Bovespa: adario@bvmf.com.br

${ }^{\S}$ Department of Economics, University of Sao Paulo. E-mail: bcg@usp.br
} 


\section{Introduction}

This paper presents clean empirical evidence that the predictive power of short-selling level over stock prices comes from two distinct channels. The first channel, related to the demand for shortselling, is due to the ability of short-sellers to anticipate movements in prices. The second, related to the supply of stock lending, is due to the fact that short-sellers are often restricted, that is, they are able to sell short less than they are willing to. These channels are based on the information hypothesis $(\mathrm{IH})$ and on the overpricing hypothesis $(\mathrm{OH})$, respectively.

According to IH, short-sellers are well informed investors with superior analytical skills and, because of that, a higher demand for short-selling should anticipate lower returns on average (Sloan 1996, Gutfleish and Atzil 2004, Diether, Lee, and Werner 2005). To test this hypothesis, ideally, the researcher would have to use data related to the demand for short-selling.

The OH, in turn, dates back to Miller (1977). Miller is the first one to theorize that short-sale constraints should lead to overpricing. More recently, new theories have been incorporating Miller's insight into refined models and their conclusions have been consistent with OH (Duffie, Gârleanu, and Pedersen 2002, Scheinkman and Xiong 2003, Chen, Hong and Stein 2002). The general idea is that overpricing will occur if investors are not able to sell short the full amount they are willing to, that is, there are short-sale constraints. In a market where short-selling is allowed, such constraints will occur when the level of stock lending supply is lower than the level of short-selling demand. Given that, ideally, observing the supply side of the lending market is a necessary condition to test $\mathrm{OH}$.

Producing clean tests of both hypotheses has been a big challenge to the empirical literature. Because of the decentralized aspect of the lending markets in most of the countries (including the US), where loan transactions are completed over-the-counter, researchers usually have historical information only related to the equilibrium of the market, that is, fees and quantities of closed lending deals. Given that, it is not easy to identify shifts in short-selling demand and shifts in lending supply, and to subsequently estimate their respective effects on stock prices.

In the present paper, we use a unique data set on stock lending activity, which contains direct information on the supply curve of the stock-lending market in Brazil. Stock lending in Brazil is centralized, with lending deals being made directly through an electronic system, called BTC. 
Lenders place shares for loan directly into the system, where borrowers can electronically hit the offers. Even though it is also possible for borrowers to place loan bids into the system, this is not usual.

Additionally, BTC allows cross-orders, where both sides are simultaneously inserted into the system by the same broker. These are transactions that were closed in advance on the over-thecounter market. To comply with Brazilian regulations, brokers must enter all deals of this kind into BTC, identifying the parties, the lending fee and amount, and all other relevant information of the deal. In sum, besides saving all lending offers that were inserted into the electronic system, the BTC data set contains historical (order by order) information on the entire securities lending market in Brazil on a daily frequency.

Based on this data set, we propose an empirical strategy that identifies the effects of shifts of both short selling demand and lending supply on stock prices. This allows us to jointly test IH and $\mathrm{OH}$ in a clean way. In a nutshell, we regress short-run future returns on the total number of shares that were lent in a given week (defined by $q^{e}$ ) and on two variables that represent the lending supply curve, namely, the total number of shares that were offered for lending through the electronic market in that week (defined by $q^{s}$ ) and the average lending fee across lending offers in that week (defined by $p^{s}$ ).

Given the ceteris paribus nature of the estimated effects, the regression coefficient related to the variable $q^{e}$ identifies the effect on stock prices of right-shifts of short-selling demand (effect A): an increase in $q^{e}$ with the lending supply curve fixed (proxied by both $q^{s}$ and $p^{s}$ fixed), can only happen if short-selling demand shifts to the right. Moreover, the regression coefficient related to the variable $q^{s}$ identifies the effect on stock prices of right-shifts of lending supply that occur along with left-shifts of short-selling demand (effect B): an increase in $q^{s}$ with both $q^{e}$ and $p^{s}$ fixed, can only happen if a right-shift in lending supply occurs along with a left-shift in lending demand.

Estimating effects $\mathrm{A}$ and $\mathrm{B}$ is useful since it allows one to jointly test $\mathrm{IH}$ and $\mathrm{OH}$ as follows. If effect $\mathrm{A}$ is found to be negative, we have evidence consistent with IH. Besides, if effect B is also negative, we conclude that $\mathrm{OH}$ also holds. We can conclude this since effect $\mathrm{B}$ is given by a combination of an increase in lending supply and a decrease in lending demand. The decrease in lending demand, according to the negative sign of effect A, should have a positive effect in prices. Hence, it must be the case that the increase in lending supply is depressing stock prices, consistent 
with $\mathrm{OH}$.

We find empirical support for both $\mathrm{IH}$ and $\mathrm{OH}$. The estimates indicate that (i) an one-standarddeviation increase in $q^{e}$ would generate a decrease in the stock price in the following 2 weeks with magnitude of -12 basis points and that (ii) an one-standard-deviation increase in $q^{s}$, would generate a decrease in the stock price in the following 2 weeks with magnitude of -27 bps. Moreover, we find that while the information channel reaches its maximum effect 2 weeks after the right-shift of the short-selling demand, short-selling restrictions have longer effects on stock prices, monotonically increasing for up to 4 weeks.

Our identification strategy is inspired in Akbas et al. (2008). They construct investment portfolios based on both the level of short selling and the level of institutional ownership of the firms. Since firms with lower institutional ownership tend to be firms with lower lending supply, exercises with double-sorted portfolios based on these two variables can produce the same identification strategy described above.

However, there are two crucial differences between the present work and Akbas et al. (2008). First, our data set contains actual shifts in the lending supply curves, instead of their proxy. Second, our data set provides daily information on the entire lending market for the stocks under analysis. Using actual data on the supply side of the lending market is important once they vary a lot in both the cross-sectional and the time-series dimensions. In turn, institutional ownership, the proxy used by Akbas et al. (2008), vary much more in the cross-section than in the time-series (institutional investors have long investment horizons). This is a problem once the time-series component under both $\mathrm{IH}$ and $\mathrm{OH}$ seems to be very relevant.

The results that we find in this paper are new if compared with the existing empirical evidence. To the best of our knowledge, there are only two other papers that propose identifications strategies to jointly test IH and OH. They are Akbas et al. (2008) and Cohen, Diether and Malloy (2007). Both papers find support only for $\mathrm{IH}$, and reject $\mathrm{OH}$.

Cohen, Diether, and Malloy (2007) use private data on both loan fees and short interests for some stocks to separately identify shifts to shorting demand and shorting supply. They proceed as follows. For a given security, in months when the average loan fee decreased but the total loan quantity increased compared to the previous month, they say that the lending supply must have shifted to the right. On the other hand, when the average loan fee increased but the loan quantity 
decreased, the lending supply must have shifted to the left. Using this strategy, they construct dummy variables that track tightening and loosening movements in the short-selling restriction for each security. Supply shifts to the left (right) indicate tightening (loosening) of short-selling sale constraints. Then, by running panel regressions, they find that while shifts in short selling demand do predict future returns, shifts in the lending supply have no significant predictive power.

An important issue with the regressions in Cohen, Diether, and Malloy (2007) is that they observe only about one quarter of the lending market for the stocks under analysis. This can lead to miscalculation of their dummy variables. For instance, an increase in the short-interest reported in their data set for a given stock, which could lead to the conclusion that the lending supply shifted to the right, may not have occurred in the overall lending market for that stock. Moreover, their method is able to identify only a small part of the supply shifts that may have occurred during their sample period. For example, if both supply and demand shifted to the right in a given month with a larger shift in demand, they would observe higher loan fee and quantity and, hence, would not identify the shift of the loan supply at all. Besides, their strategy does not differentiate between large and small shifts in lending supply, which can be a problem if the effects are increasing with the size of the shifts.

The rest of the paper is divided as follows. Section 2 describes the Brazilian stock lending market and presents our data set. Section 3 presents our identification strategy. Section 4 develops the empirical analysis. Section 5 concludes.

\section{Stock lending in Brazil}

In this section, we present information relevant to the securities lending market in Brazil. ${ }^{1}$ We chose Brazilian data due to its unique market microstructure: all lending transactions are centralized and cleared through the Brazilian Exchange (BM\&FBOVESPA). BM\&FBOVESPA is the fourth largest exchange in the word in terms of market capitalization. This exchange has a vertically integrated business model with a trade platform and clearing for equities, derivatives and cash market for currency, government and private bonds.

Regulation of the securities lending market in Brazil is determined by the Brazilian Securities

\footnotetext{
${ }^{1}$ Most of the information below is also presented in De-Losso, Genaro and Giovannetti (2013), which deals with the same data set.
} 
Commission (CVM) and by the Brazilian Monetary Council (CMN). All transactions are mediated by BM\&FBOVESPA's brokers which are responsible for bringing together opposite interests in the market place - stocks' borrowers and lenders. Any security listed on the exchange is eligible for lending.

The stock lending market in Brazil has become increasingly strong over the last 10 years, as reported in Table 1. Lending securities currently is a common practice among Brazilian market participants. In 2011, more than US\$ 400 billion in stocks were lent in more than 1.4 million deals, representing about one-third of market capitalization of about US\$1.2 trillion. These transactions involved an average of 290 companies per month. In that same year, the lenders were individuals in $40 \%$, foreign investors in $35 \%$, and mutual funds in $25 \%$ of the deals. On the borrowing side, $70 \%$ of transactions were with mutual funds, $25 \%$ with foreign investors, and $5 \%$ with individuals.

[Table 1 about here]

BM\&FBOVESPA provides a platform where brokers can register offers from their clients directly through an electronic system called BTC. Lenders place shares for loan directly into the system, where borrowers can electronically hit the offers. Even though it is also possible for borrowers to place loan bids into the system, this is not usual. More than $99 \%$ of the offers placed into BTC come from lenders.

Additionally, BTC allows cross-orders, where both sides are simultaneously inserted into the system by the same broker. These are transactions that were closed in advance on the over-thecounter market. To comply with Brazilian regulations, brokers must enter all deals of this kind into BTC, identifying the parties, the lending fee and amount, and all other relevant information of the deal.

In sum, securities lending transactions can be executed either through borrowers hitting lenders' orders on the screen, or as result of over-the-counter transaction, which according to Brazilian regulation must be cleared by BM\&FBOVESPA. In either case, the BTC saves the information for every deal. As a result, the BTC data set contains historical (order by order) information on the entire securities lending market in Brazil on a daily frequency. 
Notice, however, that the saved information related to the over-the-counter market is distinct in a crucial dimension from the saved information related to the electronic market. If a deal is closed over-the-counter, the broker saves into the system only the information related to the equilibrium of the market, that is, fees and quantities of closed deals (where supply and demand agreed with each other). Instead, when lenders place shares for loan directly into the system, the BTC saves the clean information related to the supply side of the market.

With the information contained in the BTC, it is possible to see how often a given stock is negotiated over-the-counter vis-à-vis electronically. Considering the period from January 2009 to July 2011, Figure 1 presents, stock by stock, the ratio between the volume of loans negotiated over-the-counter and the total volume (the sum of the volume negotiated over-the-counter and the volume electronically negotiated through BTC). Only stocks that traded every day in our sample period are presented in Figure 1.

[Figure 1 about here]

The y-axis indicates the importance of the over-the-counter market for the lending operations of a given stock. For the securities with the y-axis equal to 1 in Figure 1, the BTC has no direct information related to their loan supply, since their loans are always negotiated over-the-counter and all that is recorded are quantities and prices of equilibrium. For all other securities, at least some information on the actual lending supply is recorded by system. A larger portion of the supply side of a security's lending market can be observed as the y-axis value of the security decreases.

We claim that if a stock is located below the 30\%-dashed line in Figure 1, we observe a significant part of the supply side of its lending market. Indeed, for such stocks, more than $70 \%$ of the lending deals (in volume) occur through the electronic system. We denote this group of stocks by LEL (liquid and electronically lent) group. The number of stocks in the LEL group is 44 and they are listed in Table 2. The 30\% line is an arbitrary cut-off. Hence, we also present the main results of the paper for another more restrictive threshold (15\%). There are 30 stocks below the $15 \%$ threshold.

[Table 2 about here] 
How are the stocks in the LEL group different from the liquid stocks that are mostly borrowed and lent in the over-the-counter market? To investigate this, we create the LLOTC (liquid and lent over-the-counter) group, which contains the stocks that are located above the $70 \%$ horizontal dashed line in Figure 1. There are 113 stocks in this group. We then compare the LEL and LLOTC groups by size of the firms, turnover, short interest, and lending fee. We compute these measures for each month of the studied period. Size is computed as the group average market capitalization (in millions of US\$) of the firms in each month. Turnover is the average, in each group, of the stocks' monthly traded volume relative to their market capitalization. Short interest is the number of shares in loan (stock) in the end of the month relative to the number of shares outstanding. Finally, the lending fee is the group weighted average of the lending fees of the deals, that is, the fee of each deal weighted by the size of the deal. Table 3 reports the results.

[Table 3 about here]

According to Table 3, the LEL group is composed of smaller firms. In this group, the average size of a firm is US\$ 579 million. In the LLOTC group, it is US\$ 7.4 billion. It makes sense that the over-the-counter lending market concentrates its operations on larger firms, since these should generate higher lending volumes, and hence higher brokerage fees. This idea is corroborated by the fact that the short interest for the LEL group, the number of shares in loan in proportion to outstanding shares, is much smaller for the LEL group $(0.1 \%$, for the LEL stocks, and $1.4 \%$, for the LLOTC stocks). With respect to the average lending fees, the stocks in the LEL group are lent at $4.1 \%$ (per annum) on average, and the average fee for the LLOTC group is $1.9 \%$. This difference also goes in the right direction. For instance, D'Avolio (2002) examines US stock lending from a large, institutional lending intermediary and finds that while stocks from large companies are lent at $1 \%$ on average, the mean lending fees for smaller firms are about $4.3 \% .^{2}$

\footnotetext{
${ }^{2}$ Another important difference we identified between the LEL and LLOTC groups is the composition of the lenders, since lender identification is also recorded in the BTC system. Lenders who use the electronic market are very different from those who negotiate over-the-counter. Among the lending orders electronically made, $83 \%$ came from individuals, $13 \%$ from investment clubs and $4 \%$ from mutual funds. Among the over-the-counter lending orders, $45 \%$ came from mutual funds, $32 \%$ came from individuals, and $22 \%$ from foreign investors.
} 
The low short interest for the LEL stocks are due to low lending supply for such stocks in some weeks. As illustrated in figures 2 and 3 of De-Losso, Genaro and Giovannetti (2013), for many LEL stocks, there are periods when no lending offers are placed in the BTC, a clear situation of tight short-selling restriction. However, other periods show very low restrictions on short selling. Such a dynamics provides a good opportunity for testing $\mathrm{IH}$ and $\mathrm{OH}$, once its generates a large variation in short-selling restrictions and deals.

\section{$3 \quad$ Identification strategy}

As any other standard market, the stock lending market has supply (given by stock lenders), demand (given by short-sellers) and equilibrium (the lending deals). Because of the decentralized aspect of the lending markets in most of the countries (including the US), where loan transactions are completed over-the-counter, researchers usually have historical information only related to the equilibrium of the market, that is, fees and quantities of lending deals, which are take place when the short-selling demand curve crosses the stock lending supply curve. Given that, it is not easy to separate shifts in short-selling demand from shifts in lending supply, and to subsequently test IH and $\mathrm{OH}$.

For the LEL stocks defined in the previous section, we observe not only fees and quantities of closed deals, but also a significant part of the stocks lending supply. As we discuss now, with such information, we can estimate two effects:

- Effect $A$ : the effect on stock prices of a right-shift of short-selling demand;

- Effect $B$ : the effect on stock prices of an right-shift of lending supply along with a left-shift of short-selling demand.

Estimating effects $A$ and $B$ is useful since it allows one to jointly test $\mathrm{IH}$ and $\mathrm{OH}$ as follows. If effect $A$ is found to be negative, we have evidence consistent with $\mathrm{IH}$, that is, consistent with the fact that short-sellers are well informed investors with superior analytical skills.

Besides, if effect $B$ is also negative, we conclude that $\mathrm{OH}$ also holds: when lending supply shifts to the right, that is, when short selling restrictions are relaxed, stock prices go down. We can conclude this since effect $B$ is given by a combination of an increase in lending supply and a 
decrease in lending demand. The decrease in lending demand, according to the negative sign of effect $A$, should have a positive effect in prices. Hence, it must be the case that the increase in lending supply is depressing stock prices, consistent with $\mathrm{OH}$.

But how can we identify effects $A$ and $B$ ? In a nutshell, we regress short-run future returns on the total number of shares that were lent in a given week (defined by $q^{e}$ ) and on two variables that represent the lending supply curve, namely, the total number of shares that were offered for lending through the electronic market in that week (defined by $q^{s}$ ), the average lending fee across lending offers in that week (defined by $p^{s}$ ). Then, given the ceteris paribus nature of the estimated effects, the regression coefficient related variable $q^{e}$ identifies effect $A$, while the coefficient related to variable $q^{s}$ identifies effect $B$.

To understand this, note that an increase in $q^{e}$ with the supply curve fixed (proxied by fixed $q^{s}$ and $p^{s}$ ), can only happen if short-selling demand shifts to the right. Moreover, an increase in $s$ with fixed $q^{e}$ and $p^{s}$, can only happen if a right-shift in lending supply occurs along with a left-shift in lending demand. Figures 2 and 3 illustrate the identification of effects $A$ and $B$, respectively.

[Figures 2 and 3 about here]

It is obvious that $q^{s}$ and $p^{s}$ do not perfectly describe the lending supply curve, that is, there are many shapes for the lending supply curve which have the same pair $\left(q^{s}, p^{s}\right)$. Because of that, the identification of the effects $A$ and $B$ may not be perfect, and it is important to empirically test the efficacy of the identification strategy. Hence, we run the regression

$$
p_{i t}^{e}=\beta_{0}+\beta_{1} q_{i t}^{e}+\beta_{2} q_{i t}^{s}+\beta_{3} p_{i t}^{s}+\varepsilon_{i t}
$$

at the weekly frequency, using the stocks of the LEL group. The variables in equation (1) are

- $p_{i t}^{e}$ : the average of the fees across all lending deals in week $t$ for stock $i$. The average is weighted by the number of shares of each deal. It represents the lending fee of equilibrium in week $t$ for stock $i$;

- $q_{i t}^{e}$ : the number of shares in closed lending deals in week $t$ for stock $i$ (considering the whole stock lending market), relative to the number of shares outstanding for the stock. It represents 
the quantity of equilibrium in the lending market for stock $i$ in week $t$;

- $q_{i t}^{s}$ : the number of shares offered for lending in week $t$ for stock $i$, relative to the number of shares outstanding for the stock. The number of shares offered for lending in week $t$ is given by the sum of all lending offers that were placed in the electronic system in week $t$ for stock $i$;

- $p_{i t}^{s}$ : the average of the fees across all lending offers that were placed in the electronic system in week $t$ for stock $i$. The average is weighted by the number of shares of each offer. It represents the average lending fee of the week $t$ supply curve for stock $i$.

If the identification strategy is working properly, we must have

(I) $\beta_{1}>0$ : a right-shift in short-selling demand along with a fixed lending supply should produce an equilibrium with higher lending fees (Figure 4);

(II) $\beta_{2}<0$ : a right-shift in lending supply along with a left-shift in short-selling demand should produce an equilibrium with lower lending fees (Figure 5).

Besides these two tests of the success of the identification strategy, if we restrict our panel to stocks-weeks with one and only one lending offer placed on the screen, we have an additional test. In such weeks, the lending supply curve should be horizontal. Hence, we must have:

(III) $\beta_{1}=0$ : a right-shift in short-selling demand along with a fixed horizontal lending supply should produce no change on the lending fee of equilibrium;

(IV) $\beta_{2}=0$ : if the number of shares offered for lending increases, with a fixed lending fee, the horizontal supply curve gets longer (to the right). This does not change the lending fee of equilibrium;

(V) $\beta_{3}>0$ : the higher fee of the lending offer shifts the horizontal supply curve up. This produces an equilibrium with a higher lending fee.

Table 4 presents the results of regression (1) considering the full sample, to test predictions (I) and (II), and restricting the sample to stocks-weeks with one and only one lending offer placed on the screen, to test predictions (III), (IV), and (V).

[Table 4 about here] 
We first analyze the results with the full sample. Results in columns 1 and 2 are obtained, respectively, with a regression controlled for week fixed effect and a regression controlled for both week and stock fixed effect. The results are consistent with predictions (I) and (II). First, the coefficient related to $q^{e}$ is positive and significant at the $1 \%$ level, indicating that $\beta_{1}$ should be indeed identifying the effect of a right-shift of the short-selling demand curve. Second, the coefficient related to $q^{s}$ is negative and significant at the $1 \%$ level (column 1) and at the $5 \%$ level (column 2). This is the effect that would be expected from a right-shift in lending supply along with a left-shift in short-selling demand. Finally, the positive and highly significant coefficient of $p^{s}$ also goes in the right direction. In fact, an increase in the average fee of the lending offers, with $q^{e}$ and $q^{s}$ fixed, can happen with a left-shift of the lending supply curve along with a right-shift of the short-selling demand curve. Such a dynamics would lead to an equilibrium with a higher lending fee.

Turning to columns 4 and 5 of Table 4 , we find additional evidence that the identification strategy is working properly. Weeks when only one lending offer was placed on the screen should be periods with horizontal supply lending curves. In such periods, increases in $q^{e}$ and $q^{s}$ should produce no effect on the equilibrium lending fee (predictions III and IV). Only increases in $p^{s}$ (upshifts of the supply curve) should impact $p^{e}$ (prediction V). Columns 4 and 5 report results in line with such predictions. Although the coefficients $\beta_{1}$ and $\beta_{2}$ are mathematically higher than with the full sample, they are not statistically significant.

In the next section we apply the identification strategy just discussed to jointly test IH and $\mathrm{OH}$. Basically, this is done by re-estimating regression (1) using short-run future returns as the dependent variable, instead of $p^{e}$.

\section{Empirical analysis}

Our goal in this section is to determine the empirical validity of the information and the overpricing hypotheses, summarized as follows:

- Information hypothesis (IH): right-shifts of short-selling demand should predict lower shortrun future returns.

- Overpricing hypothesis $(\mathrm{OH})$ : right-shifts of stock lending supply should predict lower shortrun future returns. 
Given the discussion in the previous section, we can produce clean empirical evidence on both hypotheses by running short-run future returns on $q^{e}, q^{s}$, and $p^{s}$. With weekly observations, we estimate

$$
r_{i, t+h}=\gamma_{0}+\gamma_{1} q_{i t}^{e}+\gamma_{2} q_{i t}^{s}+\gamma_{3} p_{i t}^{s}+\alpha_{i}+\mu_{t}+u_{i t}
$$

where $h=1,2,3$, and 4 and $r_{i, t+h}$ represents the risk-adjusted return of stock $i$ for the period between week $t+1$ and week $t+h$ (inclusive). We compute the risk-adjusted returns as the residuals of time series regressions of the raw returns on the 3 Fama-French factors calculated for the Brazilian stock market. ${ }^{3}$ We use risk-adjusted returns to control for possible relations between the explanatory variables and the risk factors. The explanatory variables in equation $(2), q_{i t}^{e}, q_{i t}^{s}$, and $p_{i t}^{s}$, were already defined in the last section. Parameters $\alpha_{i}$ and $\mu_{t}$ account for stock and week fixed effects, respectively.

Table 5 presents some descriptive statistics of the variables in equation (2) that will be useful in the interpretation of the main results.

\section{[Table 5 about here]}

What do $\gamma_{1}$ and $\gamma_{2}$ indicate about the hypotheses under analysis? Since $\gamma_{1}$ identifies the effect on short-run future returns of a right-shift of short-selling demand, only $\gamma_{1}<0$ is consistent with IH. Since $\gamma_{2}$ identifies the effect on short-run future returns of both a right-shift in lending supply and a left-shift of short-selling demand, $\left(\gamma_{1}, \gamma_{2}\right)<(0,0)$ is consistent with $\mathrm{OH}$ : if $\gamma_{1}<0$, the left-shift of short-selling demand pushes $\gamma_{2}$ to be positive; hence, $\gamma_{2}<0$ can only happens if the right-shift of lending supply generates lower short-run future returns, as predicted by $\mathrm{OH}$. By the same reasoning, if $\gamma_{1}<0$ and $\gamma_{2} \geq 0$, we conclude that IH holds, but we do not have any conclusive evidence with respect to $\mathrm{OH}$ : it can still be the case the $\mathrm{OH}$ holds, but the effect from the left-shift of short-selling demand dominates and produces a positive $\gamma_{2}$.

If $\gamma_{1}=0$, we first conclude that IH does not hold. Besides, if $\gamma_{2}<0$, we conclude that $\mathrm{OH}$ holds: if $\gamma_{1}=0$, the left-shift of short-selling demand has no effect in $\gamma_{2}$; hence, $\gamma_{2}<0$ indicates

\footnotetext{
${ }^{3}$ The Fama-French factors for the Brazilian stock market were obtained from the FINBRAX - The Brazilian Center for Research in Financial Economics. The methodology and the risk factors can be found at www.fipe.org.br/web/financas/imf.
} 
that the right-shift of lending supply generates lower short-run future returns, as predicted by $\mathrm{OH}$. If $\gamma_{2} \geq 0$, we conclude that neither hypotheses hold.

If $\gamma_{1}>0$, we also conclude that IH does not hold. However, differently from the case when $\gamma_{1}=0$, if $\gamma_{2}<0$, we cannot draw any conclusion on $\mathrm{OH}$ : if $\gamma_{1}>0$, a negative $\gamma_{2}$ can simply be due to the negative effect of the left-shift of short-selling demand on future returns. As before, if $\gamma_{2} \geq 0$, we conclude that neither hypotheses hold. Table 6 summarizes the possible combinations of $\gamma_{1}$ and $\gamma_{2}$ and their respective conclusions about the hypotheses under analysis.

[Table 6 about here]

We now turn to the main results. Columns 1, 2, 3, and 4 of Table 7 present the estimates from regression (2), considering 1-, 2-, 3-, and 4-week ahead returns, respectively. The overall conclusion is favorable to both IH and OH. For 1-week ahead returns, $\widehat{\gamma}_{1}=-0.797$ ( $\mathrm{p}$-value of 0.028 ) and $\widehat{\gamma}_{2}=-0.273$ (p-value of 0.055 ). For 2-week ahead returns, both effects get stronger, with $\widehat{\gamma}_{1}=-1.162(\mathrm{p}$-value of 0.012$)$ and $\widehat{\gamma}_{2}=-0.522$ (p-value of 0.042). For 3- and 4-week ahead returns, $\widehat{\gamma}_{1}$ seems to lose strength, while $\widehat{\gamma}_{2}$ keeps increasing in absolute value. These results indicate that both $\mathrm{IH}$ and $\mathrm{OH}$ hold true and, while the information channel reaches its maximum effect 2 weeks after the right-shift of the short-selling demand, short-selling restrictions have a longer effect on stock prices throughout the overpricing channel.

[Table 7 about here]

The standard-deviations of $q_{i, t}^{e}$ and $q_{i, t}^{s}$ are, respectively, $0.105 \%$ and $0.517 \%$ (Table 5). Hence, according to column 2 of Table 7, an one-standard-deviation increase in $q^{e}$ would generate a decrease in the stock price in the following 2 weeks with magnitude of $-1.162 \times 0.105 \%=-0.12 \%$, that is, -12 basis points (bps). Besides, an one-standard-deviation increase in $q^{s}$, would generate a decrease in the stock price in the following 2 weeks with magnitude of $-0.522 \times 0.517 \%=-0.27 \%$, that is, -27 bps. 


\subsection{Excluding offers with high lending fees}

Lending offers placed in the electronic market that ask for unreasonably high lending fees should have little effect on the market equilibrium. Out of the 19,764 offers placed in the screen for the LEL stocks from January 2009 to July 2011, 617 had lending fees above 8\% per year, and 173 above 15\%. Ask and bid offers with unreasonable prices are common in electronic markets.

Even though regression (2) controls for the average of the fees across all lending offers that were placed in the electronic system in week $t$ for stock $i$, big offers with unreasonable fees can still bring noise to the estimations. To address this issue, we re-estimate regression (2) excluding the lending offers that ask for high lending fees. We do that by ranking the offers for each stock according to their fees and excluding those belonging to the highest quintile. By doing that, the sample should remain with only the lending offers with very reasonable fees, allowing the meaning of reasonable to vary across stocks. Table 8 presents the results.

[Table 8 about here]

The estimates are similar to the ones with the whole sample. For 1-week ahead returns, $\widehat{\gamma}_{1}=$ -0.801 and $\widehat{\gamma}_{2}=-0.245$. For 2 -week ahead returns, as before, both effects get stronger, with $\widehat{\gamma}_{1}=-0.975$ and $\widehat{\gamma}_{2}=-0.291$. For 3 - and 4 -week ahead returns, $\widehat{\gamma}_{1}$ loses strength, while $\widehat{\gamma}_{2}$ increases in absolute value. The conclusions are the same as before.

\section{Conclusion}

We present empirical evidence in favor of both the information hypothesis and on the overpricing hypothesis. Using a unique data set on stock lending activity, which contains direct information on the supply curve of the stock-lending market in Brazil, we propose an empirical strategy that identifies the effects of shifts of both short selling demand and lending supply on stock prices. This allows us to jointly test both hypotheses in a very clean way. Based on our results, we conclude that short-sellers are informed traders but, since they are usually able to sell short less than they are willing to, prices do not reflect all information present in the market. 


\section{Bibliografia}

Akbas, F., Boehmer, E., Erturk, B., and Sorescu, S. (2008). Why do short interest levels predict stock returns? Working paper, Texas A\&M University.

Chen, J., Hong, H., and Stein, J. (2002) Breadth of Ownership and Stock Returns. Journal of Financial Economics, vol. 66, p.p. 171-205.

Cohen, L., Diether, K., and Malloy, C. (2007). Supply and Demand Shifits in the Shorting Market. The Journal of Finance, vol. 62, n. 5, p.p. 2061-2096.

D'Avolio, G. (2002). The market for borrowing stock,. Journal of Financial Economics 66, 271306.

Desai, H., Ramesh, K., Thiagarajan, R., and Balachandran, V. (2002) An Investigation of the Informational Role of Short Interest in the NASDAQ Market. Journal of Finance, p.p. 2263-2287.

Diether, K., Lee, K., and Werner, I. (2005) Can short-sellers predict returns? Daily evidence. Working paper, Ohio State University.

Duffie, D., Gârleanu, N. and Pedersen, L. (2002) Securities Lending, Shorting and Pricing. Journal of Financial Economics, vol. 66, n.o (2-3), p.p. 307-339.

Gutfleish, R. and Atzil, L. (2004) Spotting Clues in Qs. In Short Selling: Strategies, Risks and Rewards, Frank J. Fabozzi, editor, Wiley Finance, 2004

Miller, E. (1977) Risk, Uncertainty, and Divergence of Opinion. The Journal of Finance, vol. 32, no. 4, pp. 1151-1168. 
Scheinkman, J. and Xiong, W. (2003) Overconfidence and Speculative Bubbles. Journal of Political Economy, vol. 11, n.o 61, p.p. 1183-1219

Sloan, R. (1996). Do stock prices reflect information in accruals and cash flows about future earnings? The Accounting Review, 71, p.p. 289-315. 
A Tables and Figures 


\section{Table 1: The Stock Lending Market in Brazil}

This table reports the evolution of the securities lending market in Brazil from 2000 to 2011. The second column presents the total volume negotiated in lending deals in millions of dollars. The third column reports the total volume negotiated in lending deals as a fraction of the total market capitalization. The fourth column presents the total number of lending deals in each year. The last column shows the number of stocks with at least one lending deal in each year.

\begin{tabular}{ccccc}
\hline year & volume (US\$ millions) & volume (\% mktcap) & number of deals & stocks involved \\
\hline 2000 & 1,560 & 1 & 2,530 & 30 \\
2001 & 2,790 & 2 & 11,953 & 60 \\
2002 & 2,428 & 2 & 22,486 & 68 \\
2003 & 4,374 & 2 & 39,044 & 74 \\
2004 & 8,903 & 3 & 78,729 & 116 \\
2005 & 24,664 & 5 & 166,494 & 135 \\
2006 & 50,496 & 7 & 271,210 & 156 \\
2007 & 124,106 & 11 & 568,592 & 220 \\
2008 & 174,568 & 13 & 627,414 & 251 \\
2009 & 137,483 & 19 & 711,987 & 241 \\
2010 & 265,892 & 24 & 971,558 & 261 \\
2011 & 436,302 & 32 & $1,417,787$ & 298 \\
\hline
\end{tabular}




\section{Figure 1: OTC vs. Electronic Lending Market}

This figure presents, stock by stock, the ratio between the volume of loans negotiated over-the-counter and the total volume of loans (the sum of the volume negotiated over-the-counter and the volume electronically negotiated through BTC). The period considered is January 2009 to July 2011. Each x represents a stock. Only liquid stocks, that is, stocks that were traded everyday during the sample period, are represented in the figure. The LEL group contains the stocks below the 30\%-dashed line. The LLOTC group contains the stocks above the $70 \%$-dashed line.

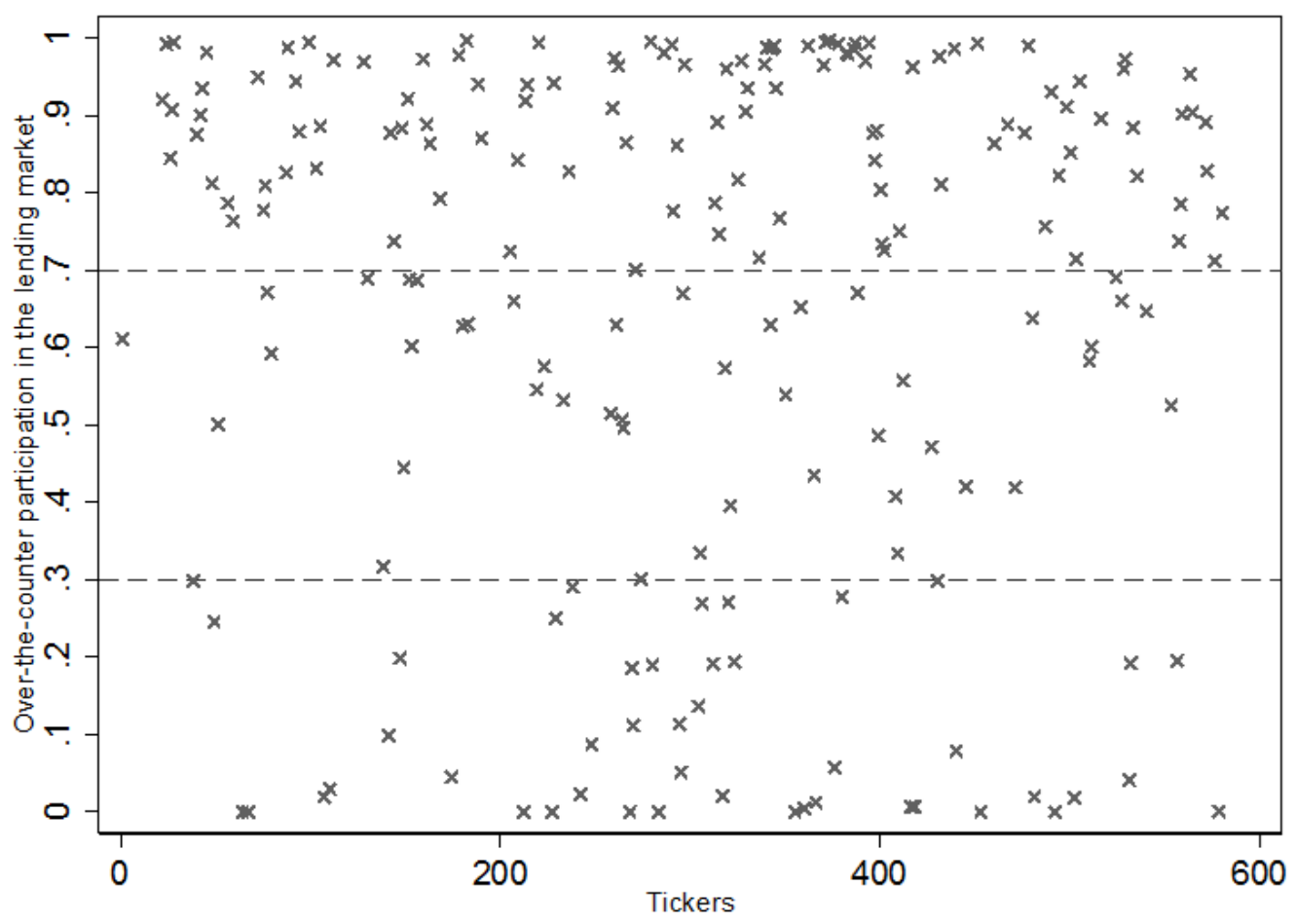




\section{Table 2: The LEL Group}

The 44 firms in the LEL group: the liquid stocks that have more than $70 \%$ of their lending deals, in volume, negotiated throughout the electronic system.

\begin{tabular}{|c|c|c|c|}
\hline stock & ticker & firm name & firm sector \\
\hline 1 & BAZA3 & Banco da Amazonia S/A & Financials \\
\hline 2 & BEES3 & Banestes S/A Banco Estado Espirito Santo & Financials \\
\hline 3 & BMIN4 & Bco Mercantil de Investimentos S/A & Financials \\
\hline 4 & BMTO4 & Brasmotor S/A & Industrial goods and services \\
\hline 5 & CBMA4 & Cobrasma S/A & Industrial goods and services \\
\hline 6 & CCIM3 & Camargo Correa Desenv. Imobiliario S/A & Construction \\
\hline 7 & CMIG3 & Cia Energ Minas Gerais - Cemig & Utilities \\
\hline 8 & COCE5 & Companhia Energetica do Ceara - Coelce & Utilities \\
\hline 9 & CTNM4 & Cia Tecidos Norte de Minas - Coteminas & Industrial goods and services \\
\hline 10 & EMAE4 & Emae-Empresa Metropolitana de Aguas e Energia S/A & Utilities \\
\hline 11 & EURO11 & Fundo de Investimento Imobiliario Europar & Real Estate \\
\hline 12 & EZTC3 & Ez Tec Empreend. e Participacoes S/A & Construction \\
\hline 13 & FHER3 & Fertilizantes Heringer S/A & Industrial goods and services \\
\hline 14 & FJTA4 & Forjas Taurus S/A & Industrial goods and services \\
\hline 15 & FRAS4 & Fras-Le S/A & Industrial goods and services \\
\hline 16 & GPCP3 & GPC Participacoes S/A & Diverse \\
\hline 17 & GPIV11 & Gp Investments, Ltd. & Financials \\
\hline 18 & GRND3 & Grendene S/A & Industrial goods and services \\
\hline 19 & HBOR3 & Helbor Empreendimentos S/A & Construction \\
\hline 20 & HETA4 & Hercules S/A - Fabrica de Talheres & Industrial goods and services \\
\hline 21 & IENG3 & Inepar Energia S/A & Utilities \\
\hline 22 & IENG5 & Inepar Energia S/A & Utilities \\
\hline 23 & INEP3 & Inepar S/A Ind e Construcoes & Industrial goods and services \\
\hline 24 & INET3 & Inepar Telecomunicacoes S/A & Telecomunication \\
\hline 25 & ITSA3 & Itausa - Investimentos Itau S/A & Financials \\
\hline 26 & JBDU3 & Inds J. B. Duarte S/A & Industrial goods and services \\
\hline 27 & JFEN3 & Joao Fortes Engenharia S/A & Construction \\
\hline 28 & KEPL3 & Kepler Weber S/A & Industrial goods and services \\
\hline 29 & MGEL4 & Mangels Industrial S/A & Industrial goods and services \\
\hline 30 & MLFT4 & Jereissati Participações S/A & Diverse \\
\hline 31 & MNPR3 & Minupar Participacoes S/A & Industrial goods and services \\
\hline 32 & MTIG4 & Metalgrafica Iguacu S/A & Industrial goods and services \\
\hline 33 & MYPK3 & Iochpe-Maxion S/A & Industrial goods and services \\
\hline 34 & PRVI3 & Companhia Providencia Ind e Comercio & Industrial goods and services \\
\hline 35 & PTBL3 & Portobello S/A & Industrial goods and services \\
\hline 36 & RCSL4 & Recrusul S/A & Industrial goods and services \\
\hline 37 & RHDS3 & M\&G Poliester S/A & Industrial goods and services \\
\hline 38 & RSIP4 & Rasip Agro Pastoril S/A & Food \\
\hline 39 & SNSY5 & Sansuy S/A Industria de Plasticos. & Industrial goods and services \\
\hline 40 & SULT4 & Construtora Sultepa S/A & Construction \\
\hline 41 & TCNO4 & Tecnosolo Engenharia S/A & Construction \\
\hline 42 & TOYB3 & Tec Toy S/A & Industrial goods and services \\
\hline 43 & TOYB4 & Tec Toy S/A & Industrial goods and services \\
\hline 44 & UNIP6 & Unipar- Uniao de Inds. Petroquimicas S/A & Industrial goods and services \\
\hline
\end{tabular}




\section{Table 3: Comparing LEL and LLOTC Groups}

The LEL (LLOTC) group contains the stocks that have more than $70 \%$ of their lending deals, in volume, negotiated in the electronic (over-the-counter) market. Both groups contain only liquid stocks (stocks that were negotiated every day during the sample period). "Size" is the group average market capitalization of the firms (in millions of US\$) in the respective month; "turnover" is the group average of the number of shares traded in the respective month relative to the number of shares outstanding; "short interest" is the group average of short interest in the respective month; "lending fee" is the group average of the lending fees (per year) of the deals in the respective month.

\begin{tabular}{ccccccccc}
\hline & \multicolumn{2}{c}{ size (millions of US\$) } & \multicolumn{2}{c}{ turnover (\%) } & \multicolumn{2}{c}{ short interest (\%) } & \multicolumn{2}{c}{ lending fee (\% p.y.) } \\
month & LEL & LLOTC & LEL & LLOTC & LEL & LLOTC & LEL & LLOTC \\
\hline Jan-09 & 425 & 4,938 & 5 & 6 & $0.10 \%$ & 0.8 & 3.8 & 2.0 \\
Jul-09 & 495 & 6,333 & 7 & 9 & 0.08 & 1.0 & 3.8 & 1.6 \\
Jan-10 & 631 & 8,333 & 21 & 8 & 0.10 & 1.2 & 5.2 & 1.8 \\
Jul-10 & 617 & 7,722 & 12 & 7 & 0.06 & 1.2 & 4.1 & 2.0 \\
Jan-11 & 678 & 9,167 & 6 & 7 & 0.08 & 1.6 & 4.0 & 1.9 \\
Jul-11 & 628 & 8,167 & 19 & 7 & 0.13 & 2.0 & 3.8 & 1.9 \\
\hline mean & 579 & 74,43 & 12 & 7 & 0.09 & 1.3 & 4.1 & 1.9 \\
\hline
\end{tabular}




\section{Figure 2: Identification of Effect A}

If lending supply is fixed, an increase in the number of shares in lending deals $\left(q^{e}\right)$ must be produced by a right-shift in short-selling demand. The fixed lending supply is proxied by a fixed average lending fee $\left(p^{s}\right)$ and a fixed total number of shares offered for lending $\left(q^{s}\right)$.

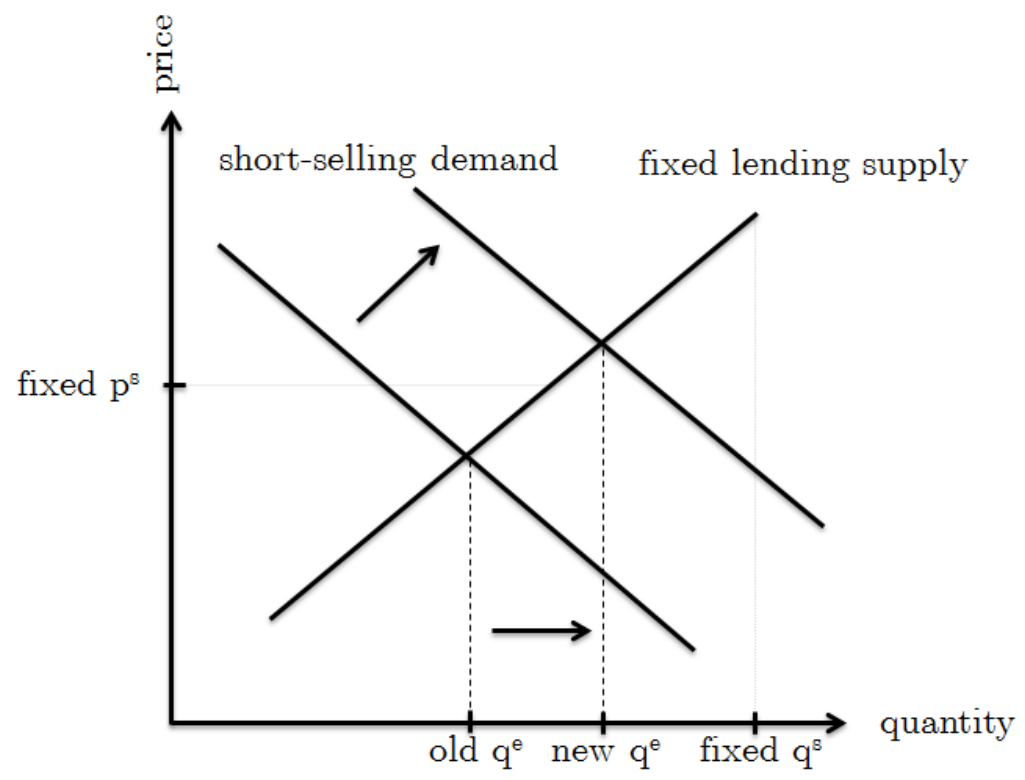




\section{Figure 3: Identification of Effect $B$}

If the number of shares in lending deals $\left(q^{e}\right)$ is fixed, a right-shift in lending supply must come along with a left shift in short-selling demand. The right-shift in lending supply is proxied by an increase in the total number of shares offered for lending $\left(q^{s}\right)$ with fixed average lending fee $\left(p^{s}\right)$.

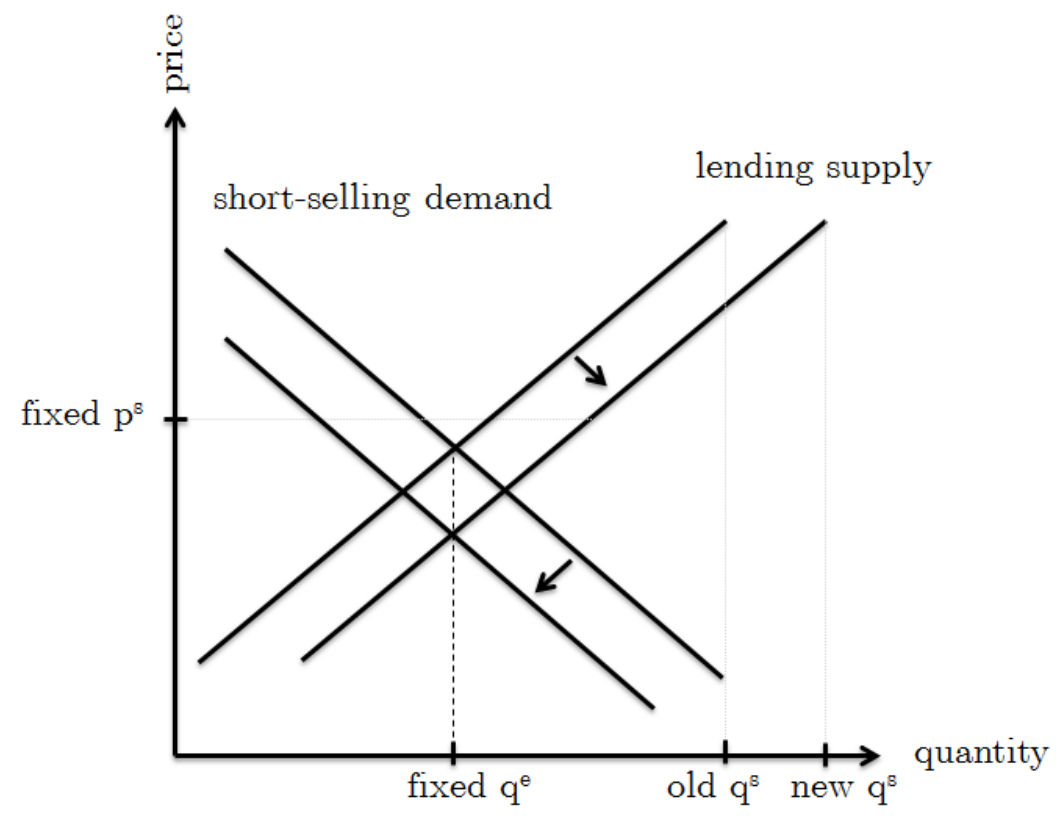




\section{Table 4: Testing the Identification Strategy}

This table reports results from panel regressions with the 44 stocks of the LEL group at a weekly frequency. The period is January 2009 to July 2011. The dependent variable, $p^{e}$, is the weighted average of the lending fees across the deals in week $\boldsymbol{t}$ for stock $\boldsymbol{i}$ (in \%) - the average is weighted by the number of shares in each deal. The explanatory variables are: (I) $q^{e}$, the number of lent shares in week $t$ for stock $i$ relative to the number of shares outstanding (in $\%$ ). (II) $q^{s}$, the number of shares offered for lending throughout the electronic system in week $t$ for stock $i$ relative to the number of shares outstanding (in \%). (III) $p^{s}$, the weighted average of the lending fees across the offers that were placed in the electronic system in week $t$ for stock $i$ (in \%) - the average is weighted by the number of shares of each offer. The regressions in columns 1 and 2 use the whole sample. The regressions in columns 3 and 4 use only the stock-week observations when only 1 lending offer was placed on the screen. The regressions in columns 1 and 3 are controlled for week dummies, and in columns 2 and 4 are controlled for both week and stock dummies. Robust standard errors are reported in paretheses. Statistical significance: * (10\% level), ** (5\% level), and *** (1\% level).

Dependent variable: Lending fee of equilibrium $\left(p^{e}\right)$

\begin{tabular}{ccccc} 
& \multicolumn{2}{c}{ Full Sample } & \multicolumn{2}{c}{ Weeks with 1 lending offer } \\
& $(1)$ & $(2)$ & $(3)$ & $(4)$ \\
\hline Quantity of equilibrium $\left(q^{e}\right)$ & $2.097^{* * *}$ & $2.027^{* * *}$ & 10.33 & 12.40 \\
& $(0.473)$ & $(0.471)$ & $(10.48)$ & $(11.35)$ \\
Lending supply $\left(q^{s}\right)$ & $-0.287^{* * *}$ & $-0.468^{* *}$ & -0.588 & -0.850 \\
& $(0.0954)$ & $(0.215)$ & $(1.055)$ & $(1.648)$ \\
& & & & \\
Lending fee $\left(p^{s}\right)$ & $0.656^{* * *}$ & $0.374^{* * *}$ & $0.500^{* * *}$ & $0.510^{* *}$ \\
& $(0.0722)$ & $(0.107)$ & $(0.159)$ & $(0.216)$ \\
Constant & & & & \\
& $0.185^{* * *}$ & $2.058^{* * *}$ & -0.0991 & 2.837 \\
Observations & $(0.0347)$ & $(0.337)$ & $(0.425)$ & $(2.633)$ \\
R-squared & 1849 & 1849 & 212 & 212 \\
Time fixed effect & 0.497 & 0.618 & 0.701 & 0.814 \\
Stock fixed effect & yes & yes & yes & yes \\
& no & yes & no & yes \\
\hline
\end{tabular}




\section{Table 5: Descriptive Statistics}

This table reports descriptive statistics of the following variables. (I) $q^{e}$, the number of lent shares in week $t$ for stock $i$ relative to the number of shares outstanding. (II) $q^{s}$, the number of shares offered for lending throughout the electronic system in week $t$ for stock $i$ relative to the number of shares outstanding. (III) $p^{e}$, the weighted average of the lending fees across the deals in week $t$ for stock $i$ - the average is weighted by the number of shares in each deal. (IV) $p^{s}$, the weighted average of the lending fees across the offers that were placed in the electronic system in week $t$ for stock $i$ - the average is weighted by the number of shares of each offer. (V) raw-ret, the raw return in week $t$ for stock $i$. (VI) $r$, the risk-adjusted return in week $t$ for stock $i$. The statistics are computed across both dimensions (weeks and stocks) of the panel.

\begin{tabular}{cccccc}
\hline (in \%) & Mean & Std. Dev. & Median & $5 \%$ percentile & $95 \%$ percentile \\
\hline Quantity of equilibrium $\left(q^{e}\right)$ & 0.013 & 0.105 & 0 & 0 & 0.055 \\
Lending supply $\left(q^{s}\right)$ & 0.123 & 0.517 & 0.002 & 0 & 0.581 \\
Lending fee of equilibrium $\left(p^{e}\right)$ & 3.79 & 4.86 & 2.70 & 0.31 & 10 \\
Rate of lending offers $\left(p^{s}\right)$ & 4.15 & 5.38 & 2.96 & 0.33 & 10 \\
Raw return $($ raw-ret $)$ & 0.66 & 8.13 & 0.00 & -9.14 & 12.50 \\
Risk-adjusted return $(r)$ & 0 & 7.92 & -0.005 & -9.56 & 11.42 \\
\hline
\end{tabular}




\section{Table 6: Possible Conclusions}

This diagram presents the possible combinations for the values of the parameters $\gamma_{1}$ and $\gamma_{2}$ from equation 2, and their respective conclusions about the tested hypotheses. Parameter $\gamma_{1}$ is the one related to the number of shares in lending deals relative to the number of shares outstanding. Parameter $\gamma_{2}$ is the one related to the number of shares offered for lending relative to the number of shares outstanding. IH stands for the information hypothesis. OH stands for the overpricing hypothesis.

$\gamma_{2}$

\begin{tabular}{|c|c|c|c|}
\hline & negative & zero & positive \\
\hline negative & $\begin{array}{l}\text { fail to reject } \mathrm{IH} \\
\text { fail to reject } \mathrm{OH}\end{array}$ & $\begin{array}{c}\text { fail to reject } \mathrm{IH} \\
\text { inconclusive on } \mathrm{OH}\end{array}$ & $\begin{array}{c}\text { fail to reject } \mathrm{IH} \\
\text { inconclusive on } \mathrm{OH}\end{array}$ \\
\hline zero & $\begin{array}{c}\text { reject } \mathrm{IH} \\
\text { fail to reject } \mathrm{OH}\end{array}$ & $\begin{array}{l}\text { reject } \mathrm{IH} \\
\text { reject } \mathrm{OH}\end{array}$ & $\begin{array}{l}\text { reject } \mathrm{IH} \\
\text { reject } \mathrm{OH}\end{array}$ \\
\hline positive & $\begin{array}{c}\text { reject } \mathrm{IH} \\
\text { inconclusive on } \mathrm{OH}\end{array}$ & $\begin{array}{l}\text { reject } \mathrm{IH} \\
\text { reject } \mathrm{OH}\end{array}$ & $\begin{array}{l}\text { reject } \mathrm{IH} \\
\text { reject } \mathrm{OH}\end{array}$ \\
\hline
\end{tabular}




\section{Table 7: Testing the Information and the Overprincig Hypotheses}

This table reports results from panel regressions with the 44 stocks of the LEL group at a weekly frequency. The period is January 2009 to July 2011. The dependent variables are 1-, 2-, 3-, and 4-week ahead risk-adjusted returns (in \%). The explanatory variables are: (I) $q^{e}$, the number of lent shares in week $t$ for stock $i$ relative to the number of shares outstanding (in \%). (II) $q^{s}$, the number of shares offered for lending throughout the electronic system in week $t$ for stock $i$ relative to the number of shares outstanding (in \%). (III) $p^{s}$, the weighted average of the lending fees across the offers that were placed in the electronic system in week $t$ for stock $i$ (in \%) - the average is weighted by the number of shares of each offer. The regressions are controlled for both week and stock dummies. Since returns are overlapping (but for 1-week ahead), the standard errors are corrected for serial correlation by clustering the observations by stocks. Statistical significance: * $(10 \%$ level $), * *(5 \%$ level $)$, and *** (1\% level).

\section{Dependent variable: Future returns}

\begin{tabular}{|c|c|c|c|c|}
\hline & $\begin{array}{c}\text { 1-week ahead } \\
\text { (1) }\end{array}$ & $\begin{array}{c}\text { 2-week ahead } \\
(2)\end{array}$ & $\begin{array}{c}\text { 3-week ahead } \\
\text { (3) }\end{array}$ & $\begin{array}{c}\text { 4-week ahead } \\
\text { (4) }\end{array}$ \\
\hline \multirow[t]{2}{*}{ Quantity of equilibrium $\left(q^{e}\right)$} & $-0.797^{* *}$ & $-1.162^{* *}$ & $-0.800^{*}$ & -0.710 \\
\hline & $(0.351)$ & $(0.441)$ & $(0.414)$ & $(0.467)$ \\
\hline \multirow[t]{2}{*}{ Lending supply $\left(q^{s}\right)$} & $-0.273^{*}$ & $-0.522^{* *}$ & $-0.802^{* *}$ & $-1.024^{* *}$ \\
\hline & $(0.138)$ & $(0.249)$ & $(0.391)$ & $(0.507)$ \\
\hline \multirow[t]{2}{*}{ Rate of lending offers $\left(p^{s}\right)$} & 0.0158 & -0.00811 & -0.0860 & -0.112 \\
\hline & $(0.0261)$ & $(0.0663)$ & $(0.0700)$ & $(0.104)$ \\
\hline \multirow[t]{2}{*}{ Constant } & $5.084^{* *}$ & $4.613^{* *}$ & 1.453 & -0.219 \\
\hline & $(1.976)$ & $(1.900)$ & $(2.647)$ & $(3.825)$ \\
\hline Observations & 3383 & 3354 & 3331 & 3307 \\
\hline R-squared & 0.152 & 0.158 & 0.163 & 0.164 \\
\hline Time fixed effect & yes & yes & yes & yes \\
\hline Stock fixed effect & yes & yes & yes & yes \\
\hline
\end{tabular}




\section{Table 8: Excluding Offers with High Loan Fee}

This table reports results from panel regressions with the 44 stocks of the LEL group at a weekly frequency. The period is January 2009 to July 2011. The dependent variables are 1-, 2-, 3-, and 4-week ahead risk-adjusted returns (in \%). The explanatory variables are: (I) $q^{e}$, the number of lent shares in week $t$ for stock $i$ relative to the number of shares outstanding (in \%). (II) $q^{s}$, the number of shares offered for lending throughout the electronic system in week $t$ for stock $i$ relative to the number of shares outstanding (in \%). To compute $q^{s}$, we do not consider the lending offers with high lending fees. These are defined in a stock by stock basis: for each stock we rank the lending offers according to their fees and divide them in 5 quantiles; the offers in the last quantile (the ones with the highest fees) are then dropped for each stock. (III) $p^{s}$, the weighted average of the lending fees across the offers that were placed in the electronic system in week $t$ for stock $i$ (in \%) - the average is weighted by the number of shares of each offer. The regressions are controlled for both week and stock dummies. Since returns are overlapping (but for 1-week ahead), the standard errors are corrected for serial correlation by clustering the observations by stocks. Statistical significance: * (10\% level), ** (5\% level), and *** ( $1 \%$ level).

\section{Dependent variable: Future returns}

\begin{tabular}{|c|c|c|c|c|}
\hline & $\begin{array}{l}\text { 1-week ahead } \\
(1)\end{array}$ & $\begin{array}{c}\text { 2-week ahead } \\
(2)\end{array}$ & $\begin{array}{c}\text { 3-week ahead } \\
(3)\end{array}$ & $\begin{array}{c}\text { 4-week ahead } \\
(4)\end{array}$ \\
\hline Quantity of equilibrium $\left(q^{e}\right)$ & $\begin{array}{c}-0.801^{* *} \\
(0.345)\end{array}$ & $\begin{array}{c}-0.975^{* * *} \\
(0.333)\end{array}$ & $\begin{array}{c}-0.701^{*} \\
(0.381)\end{array}$ & $\begin{array}{l}-0.739 \\
(0.442)\end{array}$ \\
\hline Lending supply $\left(q^{s}\right)$ & $\begin{array}{c}-0.245^{* *} \\
(0.0954)\end{array}$ & $\begin{array}{c}-0.291^{*} \\
(0.170)\end{array}$ & $\begin{array}{c}-0.517^{* *} \\
(0.222)\end{array}$ & $\begin{array}{c}-0.790^{* *} \\
(0.348)\end{array}$ \\
\hline Rate of lending offers $\left(p^{s}\right)$ & $\begin{array}{l}0.131^{* *} \\
(0.0630)\end{array}$ & $\begin{array}{c}0.107 \\
(0.104)\end{array}$ & $\begin{array}{l}-0.196 \\
(0.197)\end{array}$ & $\begin{array}{l}-0.253 \\
(0.197)\end{array}$ \\
\hline Constant & $\begin{array}{c}6.922^{* * *} \\
(1.023)\end{array}$ & $\begin{array}{c}6.163^{* * *} \\
(1.206)\end{array}$ & $\begin{array}{l}4.534^{* *} \\
(1.749)\end{array}$ & $\begin{array}{c}3.680 \\
(3.563)\end{array}$ \\
\hline Observations & 3011 & 2985 & 2963 & 2942 \\
\hline R-squared & 0.196 & 0.210 & 0.198 & 0.191 \\
\hline Time fixed effect & yes & yes & yes & yes \\
\hline Stock fixed effect & yes & yes & yes & yes \\
\hline
\end{tabular}

